\title{
Cross-cultural adaptation of the Module for Assessment of Domestic Violence, adapted from Axis I of the Operationalized Psychodynamic Diagnosis (OPD-2), with a sample of Brazilian women, victims of domestic violence
}

\author{
Adaptação transcultural do Módulo de Avaliação da Violência Doméstica do \\ Diagnóstico Psicodinâmico Operacionalizado (OPD-2) em mulheres brasileiras \\ vítimas de violência doméstica
}

Luciane Maria Both, ${ }^{1}$ (D) Taís Cristina Favaretto,${ }^{1}$ Lúcia Helena Machado Freitas,${ }^{1}$ Carla Crempien $^{2}$

\begin{abstract}
Introduction: Intimate partner domestic violence against women causes physical and psychological harm to victims. The relevance of this topic is indisputable and there is a need to identify in greater detail how these women experience violence, since these factors have considerable clinical implications.

Objective: To develop a Portuguese version of the Module for Assessment of Domestic Violence, adapted from Axis I of the Operationalized Psychodynamic Diagnosis (OPD-2), considering content validity and psychometric characteristics.

Method: Cross-cultural adaptation was based on guidelines for the process of cross-cultural adaptation of self-report measures. OPD clinical interviews were recorded and transcribed. These interviews were analyzed by two independent judges trained in the OPD-2.

Results: The sample comprised 56 women who had been victims of domestic violence, with a mean age of 30.07 years (standard deviation $=9.65$ ). The adapted version has content validity and good psychometric characteristics. Evaluation of semantic equivalence took into account the psychodynamic references, using the same ideas as the original instrument. Interexaminer reliability between the judges was substantial $(k=0.63)$ and Cronbach's alpha for the new version indicates good reliability. Conclusion: The OPD-2 offers a psychodynamic diagnosis of the victim that complements traditional nosological diagnosis, particularly in the context of domestic violence with the adaptation of Axis I. Certain biases could have been detrimental to aspects of this study, but they were controlled. The study objective was achieved and the Module was successfully adapted to Brazilian Portuguese. The results are in line with those of the original study.
\end{abstract}

Keywords: Psychodynamic, diagnosis, cross-cultural adaptation, domestic violence against women, assessment.

\section{Resumo}

Introdução: A violência doméstica por parceiro íntimo contra as mulheres causa danos físicos e psicológicos às vítimas. A relevância deste tópico é indiscutível, e é necessário identificar em mais detalhe como essas mulheres sofrem violência, uma vez que esses fatores têm implicações clínicas consideráveis. Objetivo: Desenvolver uma versão em português do Módulo de Avaliação da Violência Doméstica, adaptado do Eixo I do Diagnóstico Psicodinâmico Operacionalizado (Operationalized Psychodynamic Diagnosis - OPD-2), considerando a validade de conteúdo e as características psicométricas.

Método: A adaptação transcultural foi baseada nas diretrizes para o processo de adaptação transcultural de medidas de autorrelato. As entrevistas clínicas do OPD foram gravadas e transcritas. Essas entrevistas foram analisadas por dois juízes independentes treinados no OPD-2.

Resultados: A amostra foi composta por 56 mulheres vítimas de violência doméstica, com idade média de 30,07 anos (desvio padrão $=9,65)$. A versão adaptada demonstrou validade de conteúdo e boas características psicométricas. A avaliação da equivalência semântica levou em consideração as referências psicodinâmicas, utilizando as mesmas ideias do instrumento original. A confiabilidade entre os juízes foi substancial ( $k$ $=0,63)$, e o alfa de Cronbach para a nova versão indica boa confiabilidade.

Conclusão: O OPD-2 oferece um diagnóstico psicodinâmico da vítima que complementa o diagnóstico nosológico tradicional, particularmente no contexto de violência doméstica com a adaptação do Eixo I. Certos vieses poderiam ter sido prejudiciais aos aspectos deste estudo, mas foram controlados. O objetivo do estudo foi alcançado e o Módulo foi adaptado com sucesso para o português do Brasil. Os resultados estão alinhados com os do estudo original.

Descritores: Psicodinâmica, diagnóstico, adaptação transcultural, violência doméstica contra a mulher, avaliação.

${ }^{1}$ Universidade Federal do Rio Grande do Sul (UFRGS), Porto Alegre, RS, Brazil. ${ }^{2}$ Pontificia Universidad Católica de Chile, Santiago, Chile.

Submitted Oct 20 2018, accepted for publication Feb 112019.

Suggested citation: Both LM, Favaretto TC, Freitas LHM, Crempien C. Cross-cultural adaptation of the Module for Assessment of Domestic Violence, adapted from Axis I of the Operationalized Psychodynamic Diagnosis (OPD-2), with a sample of Brazilian women, victims of domestic violence. Trends Psychiatry Psychother. 2019;41(3):283-291. http://dx.doi.org/10.1590/2237-6089-2018-0075 


\section{Introduction}

Violence against women is unquestionably a public health problem. Data shows that $35 \%$ of women around the world are victims of physical and/or sexual violence at some point in their lives. ${ }^{1}$ According to the 2018 Atlas of Violence, compiled by the Brazilian Forum of Public Security and Institute of Applied Economic Research (Instituto de Pesquisa Econômica Aplicada [IPEA]), 4,645 women were murdered in Brazil in 2016, at a rate of 4.5 homicides per 100,000 Brazilian women. Furthermore, data predicts that over the next ten years there will be a $6.4 \%$ increase in violence against women. ${ }^{2}$

It has been observed that the statistics on domestic violence against women are alarming. It is also important to consider that the majority of women who suffer domestic violence do not report it, leading to underestimation of statistics on domestic violence against women. In the European Union, 14\% of women only reported violence to the police when the incident perpetrated by their partner was the most serious act ever committed. ${ }^{3}$ Brazil ranks in 5th place out of 83 countries for domestic violence against women. Additionally, of the 4,762 cases of homicide of females committed in 2013, 33.2\% were committed by intimate partners or former partners. ${ }^{4}$

Intimate partner domestic violence against women causes physical and psychological harm to the victims, threatening their well-being. ${ }^{5,6}$ It usually presents with slow and silent onset, without explicit physical aggression; gradually progressing to actions of greater intensity and humiliation, even public manifestations of aggression. ${ }^{7}$ It can exacerbate because of shame women feel when reporting to authorities. Women who suffer violence often do not seek help because they feel guilty and stigmatized. ${ }^{8}$

Another factor involved is social tolerance of violence against women, founded on inequalities between men and women, rigid gender roles, cultural influences that subordinate women, and insufficient legal penalties to restrain this type of behavior. It is difficult for women to leave abusive relationships, because they don't have any guarantee of safety from the abusive partner. ${ }^{9}$ It has been noted that legislation to protect the victims of violence has been widely disseminated, but establishment of standards and compliance with these laws are not yet as satisfactory. ${ }^{10}$ It is also important to mention financial insecurity; when there are children involved, how will they be provided for and where will they live? Some women remain in the violent relationships, thinking that this will be the safer option for their children and themselves.
According to the World Health Organization, acts of violence against women can have consequences varying from small to large magnitude. These include physical injuries, mental disorders such as depression that can lead to suicide, anxiety, post-traumatic stress disorder, and increased rates of clinical diseases such as hypertension and cardiac problems, among others. ${ }^{11}$

In her work, Carla Crempien has highlighted the necessity of clearly identifying the characteristics of violence against women, because these factors have clinical consequences for therapeutic results. She therefore developed the Module for Assessment of Domestic Violence to evaluate the severity, type, and duration of violence, women's suffering, and resources for and obstacles to breaking the cycle of violence, based on Axis I of the Operationalized Psychodynamic Diagnosis (OPD-2). ${ }^{12,13}$ In an empirical study that she conducted with a sample of 28 women who had been victims of domestic violence, high degrees of vulnerability of self-capacities among women who were victims of violence was proportional to high severity of violence and greater therapeutic obstacles. ${ }^{14}$

The present study describes adaptation of the English version of the Module for Assessment of Domestic Violence, ${ }^{12}$ adapted from Axis I of the OPD- $2^{13}$ to produce Brazilian Portuguese versions of the manual and the scoring form. Carla Crempien proposed adaptation of Axis I ("Experience of illness and prerequisites for treatment") of the OPD-2 to produce the Module for Assessment of Domestic Violence in her doctoral thesis in 2009. ${ }^{12,14}$

The OPD was created in 1992 in Germany by a group of psychoanalysts, psychosomatic therapists, and psychiatrists, to complement and enrich symptombased descriptions for the classification of mental disorders by adding a fundamental psychodynamic dimensions. The current edition is the 2 nd version of the operational manual, the OPD-2, which has been validated in both European Portuguese (Portugal) ${ }^{15}$ and Brazilian Portuguese, the latter in a study conducted at the Universidade Federal do Rio Grande do Sul (UFRGS). ${ }^{16}$ The OPD- 2 is a multiaxial diagnostic system comprising five axes. Four axes are psychodynamic and the fifth is descriptive, as follows: (I) experience of illness and prerequisites for treatment, (specifically in this study, the Domestic Violence Assessment Module); (II) interpersonal relationships; (III) psychic conflict; (IV) psychic structure; and (V) traditional nosological diagnosis, such as DSM and ICD. The instrument aims to formulate, identify, and center treatment planning. ${ }^{13}$

In terms of cross-cultural adaptation, it is necessary to take into account both conceptual and linguistic equivalence between the original and translated 
versions, in order to validate the resulting instrument, considering the target cultural context. ${ }^{17}$ The Portuguese and Brazilian adaptations of the OPD-2 were carried out by experienced clinical psychologists trained in the use of the instrument, respecting these countries' cultural aspects. However, empirical evidence is needed to better support the validity of the adapted versions. ${ }^{15}$

The aim of this investigation is to develop a Portuguese version of the Module for Assessment of Domestic Violence, itself adapted from Axis I of the OPD-2, considering content validity and psychometric characteristics.

\section{Method}

The study design was based on the guidelines for the process of cross-cultural adaptation of self-report measures and consists of six interdependent stages: 1) initial translations into Brazilian Portuguese; 2) synthesis; 3) back-translation; 4) expert committee; 5) pre-test; 6) submission of documentation to the developers and the author of the original instrument. ${ }^{18}$

\section{Instrument}

The Module for Assessment of Domestic Violence, ${ }^{12,14}$ has 16 items subdivided into six categories:

a) Type of violence (emotional, physical, sexual): These items refer to the different forms of expression or manifestations that domestic violence may take, and to the level of severity of each type of violence, as well as to the severity of violence as a whole.

b) Duration of the domestic violence situation: This is an indicator of the chronicity of domestic violence, so it also provides important information about the severity of the problem.

c) Intensity of subjective suffering: This item refers to the subjective suffering expressed by the victim due to intimate partner violence. This suffering must be verbalized by the woman or expressed via her gestures and/or behavior.

d) Personal concept of domestic violence: This element refers to the reasons the woman provides to explain to herself or to others why she is currently experiencing or has experienced domestic violence.

e) Concept of change: The victim's personal concept of change has to do with what she thinks would be needed for her to put an end to the situation of violence that she is experiencing.

f) Resources for and obstacles to change. These items are aimed at: first, assessing the internal and external (environmental) resources that a victim of intimate partner violence has for stopping the violence or overcoming the problem; and, second, estimating the magnitude of the obstacles, both internal and external, that keep the woman from effecting changes to the violent situation and hinder her escape from it.

These aspects are collected and explored in the OPD clinical interview. This is a semi-structured interview with specific tools for exploration of each axis, lasting approximately one hour. ${ }^{13}$ There are criteria for scoring each item according to the manual and at the end it is coded using the scoring form. For Axis I, the assessing judges will code the various dimensions and indicators described along a scale from 0 (absent), through 1 (light/insignificant), 2 (moderate), 3 (high/ significant), to 4 (very severe/very significant), or 9 (Non-assessable). ${ }^{12,14}$

\section{Ethical considerations}

This study was approved by the UFRGS ethics committee (CAAE 68271917.7.0000.5347, No. $2,412,749$ ) and permission for collection of data was obtained from the Legal Medical Department of Porto Alegre. The author of the instrument gave consent for translation and adaptation of the instrument and approved the final version of the translation.

In the fifth stage, data collection took place with voluntary participation by the victims, who signed informed consent forms authorizing use of their data for research. Their anonymity has been preserved. They answered a sociodemographic questionnaire and soon after the medical evaluation they were invited to an interview. All interviews were recorded and transcribed for further analysis.

\section{Participants}

The sample comprised 56 women who self-reported being victims of domestic violence, were aged from 18 to 65 years, and were recruited at a public sector service in the South of Brazil. Sampling was conducted by convenience. The subjects sought the service in order to obtain medical examination reports to use as proof against their partners. In most cases, they were requesting their right to protective measures under the Maria da Penha Law (Law 11.340/2006). ${ }^{5}$ This service also provides psychosocial care for victims, offering care and counseling on future legal procedures and treatment.

The sample calculation was based on Krieger's study for validation of the Brazilian OPD-2, which estimated a minimum of 53 subjects for the OPD-2 Axis I and was conducted by the GPPG at the Hospital das Clinicas 
in Porto Alegre. The calculation considered the number of items on the instrument and data in the literature on inter-rater agreement for the different axes of the instrument. The number of interviews needed was thus calculated for each axis. ${ }^{16}$ The Module for Assessment of Domestic Violence has similar numbers of items and item structures to the original OPD-2 Axis I. Additionally, in an original study researching adaptation to violence, the sample was 28 Chilean women patients attending DV treatment centres. ${ }^{12}$

\section{Procedures}

The translators of the initial versions were two Brazilian clinical psychologists proficient in English, trained in the use of the OPD-2, and familiar with psychodynamic studies. In this stage, both the manual and the scoring forms were translated from English to Portuguese. The translators chosen were healthcare experts, because the language had to reflect the clinical perspective proposed by the author. This contrasts with a self-report scale, for which the recommendation is not to use healthcare professionals as translators, since the objective is to use terms that are common to the general population. ${ }^{18}$

The types of equivalence proposed by the Guideline were analyzed for content validity. Thus, the following types of equivalence were considered: semantic (equivalence in the meaning of words), idiomatic (peculiar to a specific language), experimental (adaptation for cultural context, respecting that proposed by the original instrument), and conceptual (concept validity), which together provide instrument validation. Psychodynamic references were consulted, seeking to refer to the same ideas or objects as the original, thereby corresponding to the original version proposed by the author. In case of divergence in relation to a translation, it was discussed with other experts in OPD-2 and the author was consulted for clarification.

In the second stage, after evaluating divergence and equivalence of the translations from the previous stage, the two translators produced a single translated instrument, concluding a synthesized version of the translations. There was no divergence in this stage.

In the third stage, the back-translation was used to compare the original and the back-translation, considering content and semantic analysis. ${ }^{19}$ In common with the previous stage, there was consensus between the back-translations. The back-translation stage is important because it reflects the conceptual equivalence of the original version. ${ }^{18}$ In the fourth stage, the committee of expert judges $(n=3)$ verified the final version, approving it for pilot application in the pre-test.
The fifth stage, pre-test, was composed of two phases. First, the judges were trained to code the interviews with the new instrument. These judges already had experience with use of the OPD-2 at the Pontificia Universidad Católica de Chile, in Santiago, Chile. ${ }^{20}$

Subsequently, OPD clinical interviews were conducted with 56 women who had been victims of domestic violence. The interviews were then transcribed. Two independent judges coded the interviews according to the manual on the scoring form. It was then possible to evaluate the clarity of their translated variables.

Interexaminer reliability between the judges was evaluated using the Kappa coefficient, as per Perroca and Gaidzinski. ${ }^{21}$ The database was set up for analysis of the reliability of psychometric characteristics of the instrument and the descriptive analysis of the sample. Reliability of at least 0.60 was expected in the present study.

The final stage of the process of cross-cultural adaptation and validation, the sixth stage, consisted of submission of all reports, forms and the final version of the instrument. The original author of the instrument and the other professionals in the research team approved the final version of the Module for Assessment of Domestic Violence in Brazilian Portuguese. The Brazilian Portuguese version can be obtained from the authors upon request.

\section{Results}

\section{Content validity}

Content validity refers to the theoretical analysis of semantic aspects and the judges' analyses. ${ }^{22}$ Semantic analysis considered the understanding of the items, the explanations in the manual, and the judges' analysis to evaluate the relevance of the items in terms of their correspondence to the concept that they represent. The final version was revised in Portuguese and underwent minor adjustments in writing style and verb-noun agreement.

It was concluded that the final version produced by this study has good content validity. Thus, it is possible to comprehensibly administer the new language version of the instrument, which has consistent internal adaptation of linguistics and culture. This ensures that assessments of the impact of the context of violence will be consistent with reality. ${ }^{23}$

\section{Sample characterization}

The sociodemographic data for the sample were normally distributed, according to the Kolmogorov- 
Smirnov test of normality $(p<0.05)$. The mean age of the female victims was 30.07 (standard deviation $[S D]=9.65)$ years and the male perpetrators had a mean age of $34.8(S D=10.86)$ years. Descriptive analysis revealed that there was a predominance of white race, high school diploma, and income between 1 and 2 times the minimum monthly wage for both sexes in the sample. The women were more likely to report being religious than the men, although a high number of participants self-declared as atheists, and a higher proportion of men had substance addictions (Table 1). With regards to type of relationship, for the most part the women had been separated from their partners less than six months, from marriages lasting from 3 to 10 years (Table 2).

Regarding the types of violence, the participants suffered severe emotional violence, followed by moderate physical violence. Suffering was intense, although complaints about this were not their overriding concern in the interviews. The personal explanation of
Table 2 - Type and duration of relationship in the sample

\begin{tabular}{lc}
\hline Category & Women \\
\hline Type of relationship & $10(17.9)$ \\
Dating & $5(8.9)$ \\
Marriage & $8(14.3)$ \\
Stable partnership & $7(12.5)$ \\
Divorced & $26(46.4)$ \\
Separated for less than 6 months & \\
& \\
Duration of relationship & $3(5.4)$ \\
Less than 6 months & $6(10.7)$ \\
Between 6 months and 1 year & $11(19.6)$ \\
Between 1 and 2 years & $13(23.2)$ \\
Between 3 and 5 years & $15(26.8)$ \\
Between 6 and 10 years & $2(3.6)$ \\
Between 11 and 15 years & $4(7.1)$ \\
Between 16 and 20 years & $2(3.6)$ \\
Between 21 and 30 year &
\end{tabular}

Data presented as $\mathrm{n}(\%)$.

Table 1 - Sociodemographic characteristics of the sample

\begin{tabular}{|c|c|c|c|c|c|}
\hline Category & Women & Men & Category & Women & Men \\
\hline Age (years) & & & Complete higher education & $1(1.8)$ & $2(3.6)$ \\
\hline $18-20$ & $8(14.3)$ & $3(5.4)$ & Postgraduate studies & $1(1.8)$ & 0 \\
\hline $21-25$ & $16(28.6)$ & $5(8.9)$ & & & \\
\hline $26-30$ & $8(14.3)$ & $16(28.6)$ & Income & & \\
\hline $31-35$ & $9(16.1)$ & $13(23.2)$ & None & $13(23.2)$ & $8(14.3)$ \\
\hline $36-40$ & $8(14.3)$ & $4(7.1)$ & Less than 1 min. wage & $8(14.3)$ & $1(1.8)$ \\
\hline $41-45$ & $2(3.6)$ & $5(8.9)$ & Between 1 and 2 min. wages & $31(55.4)$ & $35(62.5)$ \\
\hline $46-50$ & $3(5.4)$ & $5(8.9)$ & Between 3 and 6 min. wages & $2(3.6)$ & $5(8.9)$ \\
\hline $51-55$ & $1(1.8)$ & $1(1.8)$ & Between 7 and 12 min. wages & $1(1.8)$ & $2(3.6)$ \\
\hline $56-60$ & $1(1.8)$ & $2(3.6)$ & More than 12 min. wages & $1(1.8)$ & $4(7.1)$ \\
\hline \multirow[t]{2}{*}{$61-65$} & 0 & $2(3.6)$ & & & \\
\hline & & & Religion & & \\
\hline Race & & & Atheist & $22(39.3)$ & $26(46.4)$ \\
\hline White & $37(66.1)$ & $35(62.5)$ & Catholic & $19(33.9)$ & $15(26.8)$ \\
\hline Black & $21(21.4)$ & $13(23.3)$ & Spiritist & $4(7.1)$ & $3(5.4)$ \\
\hline Brown & $6(10.7)$ & $7(12.5)$ & Afro-Brazilian & $3(5.4)$ & $6(10.7)$ \\
\hline Indigenous & $1(1.8)$ & $1(1.8)$ & Evangelical & 0 & $6(10.7)$ \\
\hline Educational level & & & Addiction & & \\
\hline Illiterate & 0 & $1(1.8)$ & Alcohol & $3(5.4)$ & $25(44.6)$ \\
\hline Incomplete elementary school & $15(26.8)$ & $17(30.4)$ & Tobacco & $8(14.3)$ & $7(12.5)$ \\
\hline Complete primary education & $6(10.7)$ & $6(10.7)$ & Marijuana & $1(1.8)$ & $7(12.5)$ \\
\hline Incomplete high school & $8(14.3)$ & $7(12.5)$ & Cocaine & 0 & $3(5.4)$ \\
\hline Complete high school & $22(39.3)$ & $22(39.3)$ & Marijuana and cocaine & 0 & $7(12.5)$ \\
\hline Incomplete higher education & $3(5.4)$ & $1(1.8)$ & Anabolic steroids & 0 & $1(1.8)$ \\
\hline
\end{tabular}

Data presented as n (\%). 
domestic violence refers to both internal and external factors, but these women believed in external change to resolve the violence. They presented moderate levels of internal and external resources to solve the problem and also faced obstacles to resolving it (Table 3). Their relationships are short, less than 6 months (Table 4) and the first episode of violence was on average at the age of 25.52 years.

\section{Psychometric characteristics}

The reliability between judges was substantial ( $k=$ 0.63 , minimum 0.43 and maximum 1 ), indicating that agreement wasn't by chance. Therefore, the instrument is accurate regarding the assessment criteria for the Brazilian population, more specifically women from the state of Rio Grande do Sul, South Brazil, who have been victims of violence. In a study of the Brazilian OPD adaptation, kappa varied from $57.1 \%$ to $77.7 \%$ for inter-rater agreement. ${ }^{16}$ Our results therefore point in the same direction as previous studies conducted in other countries.

In regards to internal consistency, the instrument demonstrated a Cronbach's alpha of 0.63 for the new version, which indicates that it is reliable. Table 5 presents the individual scores for the items, showing what the value of Cronbach's alpha would be after deletion of an item, but the variations that would have occurred if items had been excluded were not large.

\section{Discussion}

Cross-cultural adaptation of health instruments for use in a new country requires rigorous methodology. It is necessary to preserve content validity during linguistic and cultural adaptation, thereby ensuring that assessment of disease impact or treatment will

Table 4 - Duration of domestic violence problem

\begin{tabular}{lc}
\hline Time & Frequency \\
\hline$<6$ months & $18(32.1)$ \\
$6-24$ months & $8(14.3)$ \\
$2-5$ years & $14(25)$ \\
$5-10$ years & $6(10.7)$ \\
$>10$ years & $10(17.9)$ \\
\hline
\end{tabular}

Data presented as $\mathrm{n}(\%)$.

Table 3 - Frequency of items assessed in the Module for Assessment of Domestic Violence

\begin{tabular}{|c|c|c|c|c|}
\hline \multirow[b]{2}{*}{ Variables } & \multicolumn{4}{|c|}{ Frequency (\%) } \\
\hline & 1 & 2 & 3 & 4 \\
\hline \multicolumn{5}{|l|}{ Type and severity of violence } \\
\hline Emotional violence & 0 & $23(41.1)$ & $32(57.1)$ & $1(1.8)$ \\
\hline Physical violence & $2(3.6)$ & $33(58.9)$ & 19 (33.9) & $2(3.6)$ \\
\hline Sexual violence & $51(91.1)$ & $1(1.8)$ & $2(3.6)$ & $1(1.8)$ \\
\hline Global severity index & $1(1.8)$ & $30(53.6)$ & $23(41.1)$ & $2(3.6)$ \\
\hline \multicolumn{5}{|l|}{ Subjective experience, presentation of the problem } \\
\hline Intensity of subjective suffering & 0 & $24(42.9)$ & $31(55.4)$ & $1(1.8)$ \\
\hline Presentation of complaints of domestic violence & $1(1.8)$ & $32(57.1)$ & $23(41.1)$ & 0 \\
\hline \multicolumn{5}{|l|}{ Personal explanation of domestic violence } \\
\hline Oriented to external causes & $3(5.4)$ & $32(57.1)$ & $20(35.7)$ & $1(1.8)$ \\
\hline Oriented to psychological/interpersonal causes & $9(16.1)$ & $38(67.9)$ & $9(16.1)$ & 0 \\
\hline \multicolumn{5}{|l|}{ Change concept } \\
\hline Oriented to external modifications & 0 & $33(58.9)$ & $22(39.3)$ & $1(1.8)$ \\
\hline Oriented to personal changes & $17(30.4)$ & $22(39.3)$ & $17(30.4)$ & 0 \\
\hline \multicolumn{5}{|l|}{ Personal and external resources and obstacles to change } \\
\hline Personal resources & $13(23.2)$ & $35(62.5)$ & $8(14.3)$ & 0 \\
\hline Personal obstacles & $6(10.7)$ & $34(60.7)$ & $16(28.6)$ & 0 \\
\hline External resources & $4(7.1)$ & $45(80.4)$ & $7(12.5)$ & 0 \\
\hline External obstacles & $4(7.1)$ & $48(85.7)$ & $4(7.1)$ & 0 \\
\hline
\end{tabular}

The higher the score, the higher the severity or the rating of the variable. 
be similarly described in multinational trials. ${ }^{23}$ The psychometric characteristics assessed in the pre-test were adequate.

The objective of the present study was to develop a Brazilian Portuguese version of the Module for Assessment of Domestic Violence, itself adapted from Axis I of the OPD-2. The recommendations contained in the guidelines for the process of cross-cultural adaptation of self-report measures were followed. Thus, good content validity and satisfactory psychometric characteristics were achieved, with internal consistency of 0.63 . This contrasts with the original study, in which the internal consistency was very good: $k=0.834$ (0.483-0.972). ${ }^{14}$ However, in studies of the Portuguese and Brazilian OPD-2, the mean was 0.66 for Axis I Experience of Illness and prerequisites for treatment. ${ }^{15}$

No studies were found using the Module for Assessment of Domestic Violence other than the study conducted by the author of the original instrument. One reason for this could be that it was published recently and has not been well publicized. Additionally, use of the OPD-2 requires specific training, which limits the number of professionals who have access to it.

It was observed that the sample studied covered the different peculiarities of the population, both in regards to sociodemographic data and to experience of violence. There are differences in age, schooling, race, income, and duration and type of marital relationship. With regards to violence, there are also variations, since there were victims who had suffered intensely and for long periods and also women who reported the first violent act perpetrated by their. The explanations given for violence also varied, as did the resources for and obstacles to resolving it. These data indicate that the instrument is suitable for use in the South Brazilian setting in the context of domestic violence.

\section{Clinical implications}

In general, it is noted that the OPD-2 operationalizes psychodynamic constructs, which provides greater precision and better evidence for the field, overcoming a difficulty found in psychoanalysis to date. According to

Table 5 - Means, adjusted item-total correlations, and Cronbach's alphas if items were deleted

\begin{tabular}{|c|c|c|c|}
\hline Variables & Mean (SD) & $\begin{array}{c}\text { Adjusted item-total } \\
\text { correlation }\end{array}$ & $\begin{array}{l}\text { Cronbach's alpha if } \\
\text { item were deleted }\end{array}$ \\
\hline \multicolumn{4}{|l|}{ Type and severity of violence } \\
\hline Emotional violence & $2.61(0.53)$ & 0.54 & 0.58 \\
\hline Physical violence & $2.38(0.62)$ & 0.33 & 0.61 \\
\hline Sexual violence & $0.23(0.81)$ & 0.05 & 0.65 \\
\hline Global severity index & $2.46(0.60)$ & 0.60 & 0.57 \\
\hline \multicolumn{4}{|l|}{ Duration of domestic violence problem } \\
\hline Duration of domestic violence & $2.68(1.48)$ & 0.29 & 0.64 \\
\hline Age at first episode & $25.52(7.93)$ & -0.13 & 0.63 \\
\hline \multicolumn{4}{|l|}{ Subjective experience, presentation of the problem } \\
\hline Intensity of subjective suffering & $2.59(0.53)$ & 0.56 & 0.58 \\
\hline Presentation of complaints on domestic violence & $2.39(0.53)$ & 0.55 & 0.58 \\
\hline \multicolumn{4}{|l|}{ Personal explanation of domestic violence } \\
\hline Oriented to external causes & $2.34(0.61)$ & 0.17 & 0.63 \\
\hline Oriented to psychological/interpersonal causes & $2.00(0.57)$ & 0.26 & 0.62 \\
\hline \multicolumn{4}{|l|}{ Change concept } \\
\hline Oriented to external modifications & $2.43(0.53)$ & 0.34 & 0.61 \\
\hline Oriented to personal changes & $2.00(0.79)$ & 0.32 & 0.60 \\
\hline \multicolumn{4}{|l|}{ Personal and external resources and obstacles to change } \\
\hline Personal resources & $1.91(0.61)$ & -0.20 & 0.68 \\
\hline Personal obstacles & $2.18(0.61)$ & 0.28 & 0.61 \\
\hline External resources & $2.05(0.44)$ & 0.01 & 0.64 \\
\hline External obstacles & $2.00(0.38)$ & 0.15 & 0.63 \\
\hline
\end{tabular}

$\mathrm{SD}=$ standard deviation. 
Krieger, the OPD's operationalization provides a clinical diagnosis open to the therapist's interpretation. Also, it is useful for the training of psychotherapists, and improves communication in the scientific community. Furthermore, in the field of research, it provides more homogeneous samples than those based on descriptive diagnoses alone. It also assists in planning treatment on the basis of the most relevant psychodynamic foci. ${ }^{16}$ According to Vicente et al., the OPD-2 enables a detailed description of the symptoms and of the results of the therapeutic process in a documented and operationalized manner - for empirical investigation of the therapeutic process. ${ }^{15}$

Specifically with relation to the context of domestic violence against women, adaptation of Axis I of the OPD-2 - "Experience of Illness and prerequisites for treatment" - to produce the Module for Assessment of Domestic Violence is extremely relevant to clearly identifying the victims' experience of violence: What was the severity and type of violence suffered? How did they experience this situation? For how long? What are their explanations for the reasons that led to the violence? What resources for and obstacles to coping exist? These issues, combined with the other axes of OPD-2, provide a psychodynamic diagnosis of the victim that complements traditional nosological diagnosis. Furthermore, by understanding subjects' functioning, it is possible to carry out more effective planning of therapeutic treatment, since treatment adherence among women who have been victims of domestic violence is unsatisfactory. ${ }^{12}$

\section{Limitations}

A number of biases can be mentioned that could have been detrimental to the results of this study. However, many of these were controlled, as far as was possible. These biases are related to reliability between judges, sample, procedures, and location of collection, evaluation, and translation.

With respects to judges' reliability, some interviews didn't have a good coefficient of agreement between judges: lower than 0.60. In these cases, we decided not to repeat the codification in order to avoid conditioning evaluation of these items or inferring a certain interpretation from the judge. Additionally, the sample did not include a significant number of victims of sexual violence, so evidence in this respect was insufficient, since the literature shows that there are peculiarities in this population in terms of greater severity. Another feature of the sample was the very low educational level of some of the women, which could have limited their ability to fully express themselves and to be understood fully.
Additionally, interviews were coded on the basis of audio transcriptions only, so patients' non-verbal behavior was not evaluated. Sometimes, these expressions were maintained in reports, such as crying, anger, among others. The site of data collection must also be taken into account, because it was not a clinical setting, but a police station where subjects present with the intention of filing a report against someone and of seeking protection. Thus, in some cases, there was a high level of defense mechanisms or even dissociative defenses that could distort facts. Nevertheless, these issues reveal how such victims experience violence. Also, part of the interview was dedicated to counseling the victims on legal procedures. Victim's demands were met regardless, but always based on the OPD clinical interview.

Finally, instrument translation - of the scoring form and the manual - were performed by two Brazilian psychologists proficient in English, but not by professional translators. This choice was made to ensure use of the correct psychodynamic terms, but could have distorted terms in the final version. For this reason, it is vital that professionals who use the adaptation of the OPD- 2 have prior knowledge of this theoretical approach and are trained in the OPD-2 Task Force, so that assessments are consistent with patients' lives and experiences.

\section{Conclusion}

The OPD-2 has been validated in several countries and cultures (Germany, England, Italy, Chile, Australia, Portugal, and Brazil). There is now an opportunity to use an adaptation of Axis I for the context of domestic violence, based on the original Experience of illness and prerequisites for treatment items. The cross-culturally adapted Module for Assessment of Domestic Violence is based on the OPD-2 Axis I, is validated with Brazilian women who have been victims of domestic violence, and was produced according to the guidelines for the process of cross-cultural adaptation of self-report measures.

The study objective was achieved and the Module for Assessment of Domestic Violence from the OPD clinical interview was successfully adapted to Brazilian Portuguese. The final version of the instrument demonstrated applicability in women with different sociodemographic characteristics - age, income, schooling, and type of relationship - although data collection took place in the South of Brazil. The study's guaranteed applicability is for the population of Rio Grande do Sul and further research must be carried out in order to enable validation for the wider Brazilian population. 
According to the initial empirical evidence described here, the adapted version of the instrument is adequate and offers good reliability. The results are consistent with the original study. Instrument translation resulted in satisfactory content validity and its internal consistency suggests that the instrument has adequate psychometric characteristics. However, further studies are still needed to confirm the validity and reliability of the version developed in the present study. There is a need for further studies with more extensive samples and these should consider inclusion of other variables to achieve external validity and recruit samples from other regions of the country, in order to obtain more reliable indicators of the instrument's validity.

\section{Acknowledgements}

This study was partially financed by the Coordenação de Aperfeiçoamento de Pessoal de Nível Superior (CAPES; Finance Code 001).

\section{Disclosure}

No conflicts of interest declared concerning the publication of this article.

\section{References}

1. World Health Organization. Responding to intimate partner violence and sexual violence against women. WHO clinical and policy guidelines. Geneva: WHO; 2013. https://apps.who.int/iris/ bitstream/handle/10665/85240/9789241548595 eng.pdf

2. Instituto de Pesquisa Econômica Aplicada. Atlas da violência 2018. Rio de Janeiro: IPEA; 2018. http://www.ipea.gov.br/portal/ images/stories/PDFs/relatorio_institucional/180604_atlas_da_ violencia_2018.pdf

3. European Union Agency for Fundamental Rights. Violence against women: an EU-wide survey. Main results report. Vienna: FRA; 2014. https://fra.europa.eu/en/publication/2014/violenceagainst-women-eu-wide-survey-main-results-report

4. Waiselfisz Jj. Mapa da violência: mortes matadas por arma de fogo. Brasília: Secretaria-Geral da Presidência da República, Secretaria Nacional de Juventude, Secretaria de Políticas de Promoção da Igualdade Racial; 2015.

5. Brasil, Casa Civil. Lei no 11340, de 7 de agosto de 2006. http:// www.planalto.gov.br/ccivil_03/_ato2004-2006/2006/lei/l11340. htm

6. Cortez MB, Souza L, Queiróz SS. Violência entre parceiros íntimos: uma análise relacional. Psicol Polit. 2010;10:227-43.
7. Leôncio $\mathrm{KL}$, Baldo $\mathrm{PL}$, João VM, Biffi RG. O perfil de mulheres vitimizadas e de seus agressores. Rev Enferm UERJ. 2008;16:30712.

8. World Health Organization. Strengthening health systems to respond to women subjected to intimate partner violence or sexual violence: a manual for health managers. Geneva: WHO; 2017.

9. Krug EG, Dahlberg LL, Mercy JA, Zwi AB, Lozano R. World report on violence and health. Geneva: World Health Organization; 2002.

10. World Health Organization. Global status report on violence prevention. Geneva: WHO; 2014.

11. World Health Organization. Global plan of action: to strengthen the role of the health system within a national multisectoral response to address interpersonal violence, in particular against women and girls, and against children. Geneva: WHO; 2016.

12. Crempien C. Adaptación específica del Eje I OPD para la evaluación de mujeres que sufren violencia en la pareja: Módulo de Evaluación de Violencia Doméstica [monograph]. Santiago: Pontificia Universidad Católica de Chile; 2009.

13. Grupo de Trabajo OPD. Diagnóstico Psicodinámico Operacionalizado (OPD-2): Manual para el diagnóstico, indicación y planificación de la psicoterapia. Barcelona: Herder; 2008.

14. Crempien C. Psychological and relational functioning in Chilean women victims of domestic violence, with different levels of childhood relational adversity [thesis]. Heidelberg/Santiago: Heidelberg University/Pontificia Universidad Católica de Chile/ Universidad de Chile; 2012

15. Vicente CS, Oliveira RA, Silva FS, Ferrajão $P$, Augusto $S$, Oliveira SM, et al. Cross-cultural adaptation of the Operationalized Psychodynamic Diagnosis (OPD-2) in Portugal. Trends Psychiatry Psychother. 2012;34:129-38.

16. Krieger DV. Operationalized Psychodynamic Diagnosis 2: apresentação da versão brasileira e estudos preliminares de validade e confiabilidade [dissertação]. Porto Alegre: Universidade Federal do Rio Grande do Sul; 2013.

17. Santana MRM, da Silva MM, de Moraes DS, Fukuda CC, Freitas $\mathrm{LH}$, Ramos ME, et al. Brazilian Portuguese version of the COREOM: cross-cultural adaptation of an instrument to assess the efficacy and effectiveness of psychotherapy. Trends Psychiatry Psychother. 2015;37:227-31.

18. Beaton DE, Bombardier C, Guillemin F, Ferraz MB. Guidelines for the process of cross-cultural adaptation of self-report measures. Spine. 2001;25:3186-91.

19. Cunha J. Psicodiagnóstico-V. 5a ed. Porto Alegre: Artmed; 2000.

20. Pontificia Universidad Católica de Chile. Diplomado en Diagnóstico, Indicación y Estrategias en Psicoterapia: diagnóstico Psicodinámico Operacionalizado (OPD-2) - Semi presencial [Internet]. [cited 2019 Feb 11]. http://diplomados.uc.cl/28618ficha-diplomado-en-diagnostico-indicacion-y-estrategias-enpsicoterapia-diagnostico-psicodinamico-operacionalizado-opd-2

21. Perroca MG, Gaidzinski RR. Assessing the interrater reliability of an instrument for classifying patients: kappa quotient. Rev Esc Enferm USP. 2003;37:72-80.

22. Pasquali, L. Princípios de elaboração de escalas psicológicas. Rev Psiquiatr Clin. 1998;25:206-13.

23. Beaton $D E$, Bombardier $C$, Guillemin $F$, Ferraz MB. Recommendations for the cross-cultural adaptation of the DASH and QuickDASH outcome measures. Ontario: Institute for Work \& Health; 2007.

\section{Correspondence:}

Luciane Both

Rua Ramiro Barcelos, 2350

90035-903 - Porto Alegre, RS - Brazil

Tel.: +55 (54) 996145522

E-mail: lucianeboth@gmail.com 